\title{
Physical therapy management in knee ankylosis -Case study-
}

\author{
Ana-Maria VUTAN ${ }^{1}$
}

\begin{abstract}
Aim: The purpose of this paper is to present a complicated case of a 2.8 year-old child with knee synovitis of unknown etiology which complicated in a very short time by the appearance of an ankylosis. The removal of the cast after 3 weeks revealed stiffness in flexion of the affected knee. Neither physiotherapy nor attempts to mobilize under anesthesia, led to the expected results. Consequently, the patient was referred to a surgery service for the adherence removal by arthrotomy. During the following 5 months, new complications developed due to a double tibia and peroneal fracture. After the consolidation of the fractures, both the therapist and the recovery protocol were changed.

Method: For one and a half years, the child followed two weekly recovery sessions consisting in physiotherapy and massage. At home the child did an exercise program under parental supervision and worn an orthosis.

Results: At the end of the rehabilitation program we noticed the restoring the normal amplitude of all the lower limb joints, restoring the muscular strength of the lower limb, and normal course resumption.

Conclusion: In addition to the need for a correct diagnosis of the disease, such cases also require an adequate recovery protocol, following the instructions given by the treating physician and to ensure continuity of the rehabilitation program (both in a recovery and home program), until the complete rehabilitation of the deficit.
\end{abstract}

Key words: knee ankylosis, child, recovery protocol

\section{Rezumat}

Scopul: Scopul acestei lucrări este prezentarea unui caz complicat ce a dus la anchiloza în flexie a genunchiului unui copil de 2 ani si 8 luni, în urma unei sinovite de etiologie necunoscută. După suprimarea aparatului gipsat purtat timp de 3 saptămâni se constată o redoare in flexum a genunchiului afectat. Nici sedinţele de kinetoterapie şi nici încercarea de mobilizare sub anestezie nu au dat rezultatul scontat astfel s-a recurs la intervenţie chirurgicală ce a urmărit îndepărtarea aderenţelor prin artrotomie. În următoarele 5 luni au intervenit noi complicaţii, respectiv apariția unei duble fracturi de tibie şi peroneu. După consolidarea acestei fracturi s-a schimbat terapeutul şi protocolul de recuperare.

Metodă: Timp de un an şi jumatate copilul a urmat câte 2 şedinte de recuperare pe săptămână ce au constat din masaj şi gimnastică medicală. La domiciliu copilul a executat un program de exerciții sub supravegherea parințior și a purtat orteză. Rezultate: La finalul perioadei de recuperare s-a obtinut: refacerea amplitudinii normale la nivelul tuturor articulațiilor membrului inferior, refacerea forţei musculare la nivelul membrului inferior şi reluarea normală mersului.

Concluzie: Pe lângă necesitatea diagnosticării corecte a afecţiunii este nevoie de realizarea unui protocol adecvat de recuperare, de respectarea indicaţiilor medicului curant şi de continuitate în programul de reabilitare (atât în cadrul unui cabinet de recuperare cât și la domiciliu) până la refacerea completă a deficitului.

Cuvinte cheie: anchiloza genunchiului, copil, protocol de recuperare

\footnotetext{
${ }^{1}$ Kinetotherapist, Student PhD, Mechatronic Department, Politehnica University Timișoara, Romania, e-mail: anamariavutan@yahoo.com
} 


\section{Introduction}

The knee is the largest joint in the human body being only slightly covered and being surrounded by soft tissue. The knee joint is a single-freedom joint and belongs to the group of condylar joints. [1].

Thus, the knee joint permits flexion and extension as well as slight internal and external rotation of the lower limb. Studies have shown that, on a sagittal plane, during flexion and extension there are intracapsular rolling movements of the femur on the tibia for the first $15^{\circ}$ of flexion, followed by glides and rotations of the tibia on the femur [2]. Any anomaly in performing these movements induces pathological pressures on the joint cartilage.

The knee has a double role: static, when stationary, and dynamic, during walking. Thus, any knee disorder will result in both locomotor and stationary problems.

The extension movement of the knee is considered as having $0^{\circ}$, while the flexion movement has $140^{\circ}-$ $145^{\circ}$. During its daily movements, the knee is not mobilized to its maximum amplitude. For example, in normal walking flexion reached $50^{\circ}-70^{\circ}$, when sitting flexion reaches $90^{\circ}-95^{\circ}$, when walking down the stairs flexion reaches $100^{\circ}$, and for tying one's shoelaces flexion reaches $105^{\circ}$ [2]. Despite all these, a flexion deficit of over $100^{\circ}$ may occur as a handicap for the affected person.

Knee pathology is extremely diverse as it may involve soft and/or bony parts in various types of disorders: rheumatic, post-traumatic, postoperative, neurological. These disorders may impair mobility, muscle strength, stability, controlled movement or ability.

The assessment of an impaired knee consists in: patient history (the patient gives a detailed description of the symptoms and the onset of the disorder), clinical exam (the physician assesses the movements of the knee to locate pain and to assess the limitation of the movements), laboratory exams and imaging (lab tests, X-rays, CT scan, MRI, scintigraphy, arthroscopy) [3].

According to the diagnosis, the treating physician may refer the patient to a center of medical recuperation in order to recover the lost functions.

\section{Case study}

In 2013, at the begining of September, the child aged 2 years and 8 months, began to accuse knee pain, mainly in the morning and during the first hours of the day. He presented a tendency to limp, due to lack of knee flexion. The child was taken to the emergency room of the Luis Turcanu Children's Hospital, Timisoara, where he was consulted by a pediatric orthopedist and where his knee was Xrayed. Radiography showed no alterations of the right knee joint and the child was given an analgesic and anti-inflammatory treatment to be administered at home, for 5 days (Fastum gel locally and Nurofen orally). However, the child's condition worsened, the right knee became swollen, red and warm. A second examination was associated by another X- ray and inflammatory tests, the child being suspected of juvenile arthritis due to the existing symptoms (joint pain, morning stiffness, refusal to walk, protection of the knee, limping).

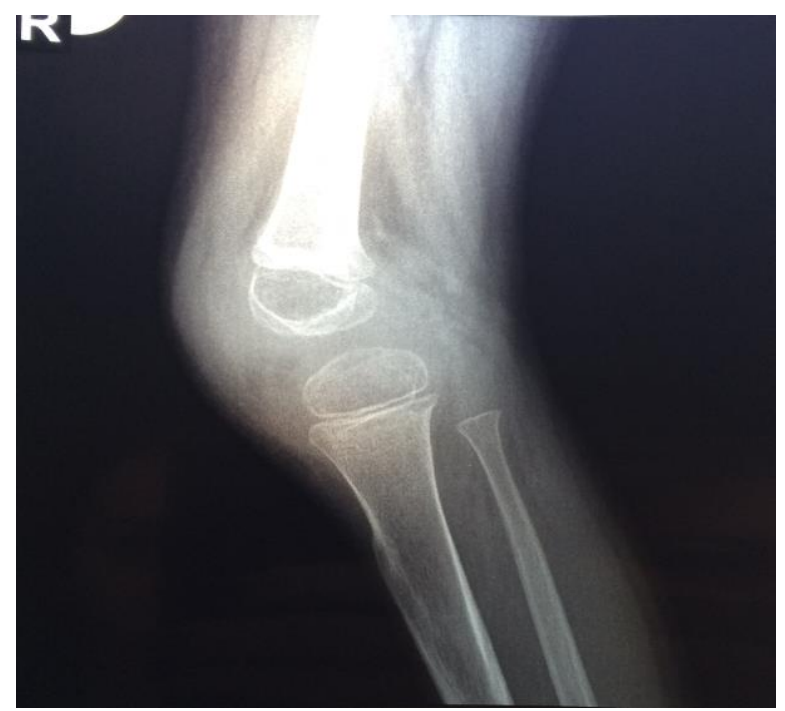

Figure 1. Right knee joint (second X-ray)

This diagnosis was eventually invalidated by the rheumatologist, and the orthopedist recommended MRI which revealed liquid accumulation requiring a synovial fluid puncture. The analysis of the synovial fluid led to the diagnosis of right knee synovitis with secondary hydrarthrosis. The impaired limb was immobilized in a fixed orthosis for three weeks. After the removal of the orthosis, the child flexed the knee and the knee remained in flexed position. The parents took the child to a clinic of recuperation in order to mobilize the knee and restore movement 
amplitude. As therapists found it impossible to mobilize the right knee, the child was referred to another orthopedic examination. This time the parents chose to take the child to the pediatric clinic in Szeged (Hungary) for further investigations. Due to the fact that under general anesthesia the knee could not be completely extended, at the end of February 2014 surgery was performed in order to remove intraarticular adherences which were extended between the synovial membrane and the articular surfaces. After surgery, the knee could be fully extended and the child was discharged from hospital without any inflammatory signs, with the indication to use a gypsum splint which would allow the knee to maintain its extended position. The orthosis could be removed for a few hours a day so that the child could practice flexion movements and follow a recuperation treatment guided by a therapist. Unfortunately, the recuperation therapy did not yield the desired results, and after changing three different therapists, in July 2014, some mobilization manoeuvers of the knee resulted in a double tibial and peroneal fracture.

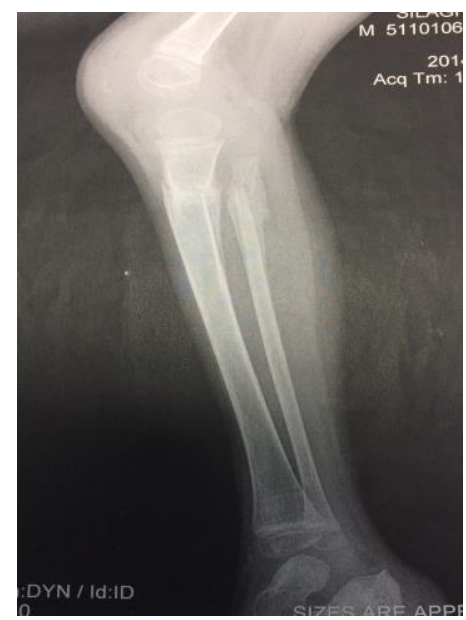

Figure 2. Double tibial and peronial fracture

After the consolidation of the fracture, the parents again resorted to a medical recuperation therapist, specialized in pediatric orthopedics, where another therapeutic protocol was instituted, under the observation of a pediatric orthopedist. The clinical exam carried out before the beginning of the treatment showed the following:

- $20^{\circ}$ extension deficit,

- $90^{\circ}$ knee flexion,

- $\quad$ severe valgum position of the knee,
- outwardly fixated knee cap,

- the foot fixated in plantar flexion with rigid foot joints,

- outwardly oriented right hip,

- $\quad$ severe muscle atrophy of the entire right lower limb.

- $\quad$ impossibility of independent walking (the child had to be carried),

Taking into account the particularity of this case, the recuperation protocol consisted in:

- massage,

- medical gymnastics twice a week, at a kinesiotherapy rehabilitation center,

- daily exercises at home under the supervision of the father (the exercises were prescribed by the therapist),

- daily use of the orthosis.

Kinesiotherapy primarily aimed the mobilization of the knee and foot joints, followed by regaining the strength of all affected muscle groups: back, pelvic, thigh, calves [4].

The following procedures were applied: passive manoeuvers to stretch retracted muscles and tendons, movements of the knee and patella as well as of all foot joints. The set of exercises also included passive-active, active and resistancesactive exercises. The results consisted in an increase strenght of the knee extensors muscles and of the muscles responsible for the dorsiflexion of the foot. In February 2015, the child managed to step on the leg (so far the child only crawled on all fours), with a certain knee extension deficit of $5^{\circ}-6^{\circ}$.

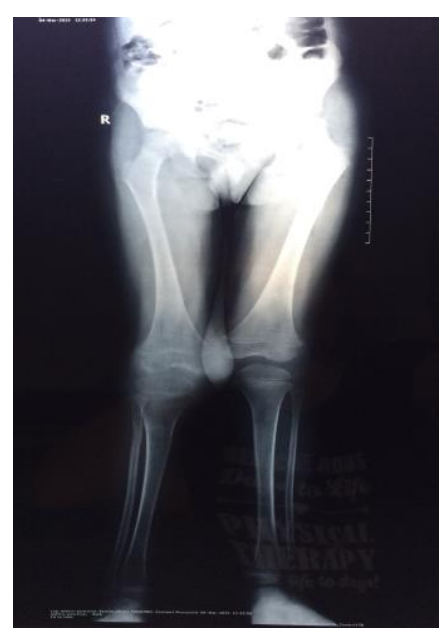

Figure 3. Standing position after the first verticalization in February 2015 
The further objectives of the rehabilitation program aimed :

- strengthening right lower limb muscles,

- balancing the pelvis,

- acquiring age-specific motricity .

These objectives were successfully reached until the spring of 2016 when recuperation treatment was eventually concluded. The child, who now was already five, had a fully mobile knee and foot, a right-limb muscle strength of F4 - F5, being able to walk and run by himself. The only drawback was an asymmetry in the length of the lower limbs, which can be corrected with proper insoles.

\section{Discussion}

In the literature, cases of knee ankylosis are presented in children diagnosed juvenil arthritis. In these cases, surgery was performed by lysis of adhesions, tendon lengthenings, capsular releases, cruciate ligament release, drilling of subchondral bone and patellectomy or meniscectomy. Surgery was followed by immediate continous passive motion (CPM) for 6 weeks, which has led to the restoration of the movement amplitude at the knee. In the case of the patient presented in this study, the passive movement recommended by the orthopedic surgeon was not performed, the orthesis was not worn and shortly the knee was again fixed in flexum. The recovery period of the knee after surgery was prolonged due to complications that occurred in the following months.

\section{Conclusion}

The complexity of this case was due to the lack of a clear diagnosis from the begining, the young child's age, the presence of inflammation and swelling over a long periods of time, the double tibia and peroneal fracture resulting from the mobilization maneuvers as well as the changes in the axel of the inferior limb. The first signs of pain occurred when the child was 2.8 years old, and final recuperation was achieved at the age of 5.3 years old, with the following results: full knee and leg movement amplitude, muscle strength recovery, normal gait and, implicitly, resuming all age-specific activities.

\section{References}

1. Papilian V. (1998). Anatomia omului, vol. I, Editura All, București,139-140.

2. Sbenghe T. (2002). Kinesiologie, ştiința mişcării, Editura Medicală, București, 275-284

3. Sirbu E., (2007). Kinetoterapia în afecţiuni reumatologice, Editura Eurobit, Timişoara, 141-155.

4. Sbenghe T. (1987). Kinetologie profilactică, terapeutică și derecuperare, Editura Medicala, București, 360-384. 